\section{Development of Ultrashort Light Sources and Study on Nonlinear Microspectroscopy}

Do-Kyeong KO, Ju Won CHOI, Kyu-Sup LEE, Jang-Hyuk LEE and Byoung-uk SOHN

Because of the development of ultrashort lasers during the last three decades, ultrafast and nonlinear optics has extended its research area to physics, chemistry, biology, life science, laser micromachining, and so on. Many research groups in Korea are studying the development of novel ultrashort intense light sources, energy-related optical materials and devices, and the electronic structures of energy/nano/bio materials and their dynamics. Here, we introduce some research activities for the development and manipulation of novel ultrashort light sources and of nonlinear microspectroscopy.

\section{머리말}

극초단 비선형 광학연구는 지난 30여 년간 극초단 레이저 개발의 비약적인 발전이 이루어지면서 물리학뿐만 아니라 화 학분야, 생명과학분야 및 레이저 미세가공분야 등으로 그 연 구 영역이 급격히 확장되어 왔다. 국내에서도 여러 연구그룹 에서 극초단 고출력 광원 개발과 이를 이용한 에너지 관련 광소재/소자 개발, 에너지/나노/바이오 물질의 전자구조 및 관련 동력학 등을 연구하고 있다. 여기서는 극초단 비선형 광 학연구를 위한 새로운 광원 개발과 조작, 그리고 생명과학분

\section{저자약력}

고도경 교수는 서울대학교 물리학 박사(1992)로서 한국원자력연구원 책임연 구원(1992-2003)을 거쳐 광주과학기술원 고등광기술연구소 및 광공학응용 물리학과 교수(2003-현재)로 재직 중이며, 과학기술진흥유공 국무총리 표 창(2011)을 수상하였고 현재 국제 양자전자학 평의회(ICQE) 위원, 한국연 구재단 자연과학단 전문위원(RB), 극한광 응용기술 국가핵심연구센터 제2 총괄과제책임자, 한국물리학회 광학 및 양자전자분과위원장으로 활동 중이 다. (dkko@gist. ac.kr)

최주원, 이규섭, 이장혁, 손병욱은 현재 광주과학기술원 광공학응용물리학 과 박사과정 중에 있다.
야에의 응용연구에 대하여 간단히 소개한다.

\section{극초단 비선형 광학용 준위상정합소자 개발 및 $\mathrm{THz}$ 파 발생연구}

빛이 물질과 상호작용할 때 물질 내의 원자들이 반응하게 되는데, 이때 원자들의 쌍극자모멘트가 진동하게 된다. 일반 적으로는 외부전기장에 물질이 선형적으로 반응하게 되어 입 사된 전기장과 같은 주파수를 가지는 분극파가 발생되게 된 다. 그런데 외부전기장의 세기가 매우 커지면 원자들의 반응 이 비선형적이 되어 쌍극자모멘트가 입사된 전기장과 다른 주파수를 가지면서 진동하는 경우가 발생된다. 특히 발생하는 분극파가 전기장의 제곱에 비례하는 이차비선형현상은 전기 장의 세기가 커질 경우 무시할 수 없으며 이를 통해 굴절률 의 변화, 빛의 파장변화와 같은 현상을 관찰할 수 있다. 그러 나 이러한 비선형현상을 일으키기 위해서는 물질 내의 원자 들이 비선형적으로 반응할 수 있는 충분히 강한 빛이 필요하 다.

J. A. Armstrong은 1962년에 비선형 물질 내 빛의 상호 작용에 대한 이론을 발표하면서 준위상정합(Quasi-Phase Matching)이라는 개념을 제시하였다. ${ }^{[1]}$ 이에 따르면, 매 결맞 음길이마다 물질의 자발분극을 역전시킴으로써 결정 내에서 분산에 의해 발생되는 입력파와 상호작용하는 파의 위상속도 차를 의도적으로 보상해줄 수 있으며, 따라서 조화파의 세기 를 증가시킬 수 있다는 것이다. 준위상정합은 다른 위상정합 방식과는 다르게 비선형 결정의 길이를 길게 할 수 있고 투 명영역 내에서는 파장에 제한이 없으며 가장 큰 비선형계수 를 사용할 수 있어서 높은 파장변환효율을 얻는데 효과적이 다. 그러나 이러한 준위상정합을 이용하기 위해서는 주기적으 로 분극반전된 소자의 제작이 필수적이다. 특히, 가시광선 영 역 대의 파장을 얻기 위해서는 일반적으로 수 $\mu \mathrm{m}$ 대의 주기 를 가지는 준위상정합 소자를 만들기 위한 분극반전 기술이 요구된다. 준위상정합 소자는 일반적으로 자발분극을 가진

\section{REFERENCES}

[1] J. A. Armstrong, N. Bloembergen, J. Ducuing and P. S. Pershan, Phys. Rev. 127, 1918 (1962). 


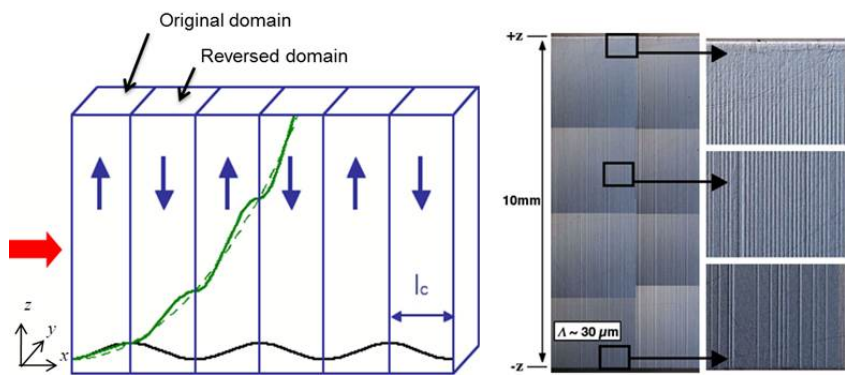

Fig. 1. (left) Harmonic intensity in periodically poled crystal. The arrows show the polarization direction and $I_{c}$ is coherence length. The black curve presents the non-phase matched harmonic intensity along the interaction length, whereas green curve shows the increased harmonic intensity by reversing the polarization periodically at each coherence length. Reversed domain means the area which has reversed polarization by external field. (right) Y-cut photographs of typical periodic structure in 10-mm-thick $\mathrm{MgO}$ doped $\mathrm{LiNbO}_{3}$ with QPM period around $30 \mu \mathrm{m} .{ }^{[2]}$

$\mathrm{LiNbO}_{3}, \mathrm{LiTaO}_{3}, \mathrm{KTiOPO}_{4}(\mathrm{KTP})$ 와 같은 강유전체로부터 많 이 제작된다. 1980년대 결정성장을 통한 준위상정합소자의 개발을 시작으로 90 년대에는 상온전기장폴링법이 개발됨에 따라 두께가 수백 $\mu \mathrm{m}$ 이상인 소자의 제작이 가능하게 되었 다.

준위상정합소자는 파장변환을 기본으로 다양한 활용성을 지니고 있다. 우선, 파장가변용 광매개공진기 제작에도 이용 되며 이를 통해 적외선 레이저를 이용한 녹색광 발생에 응용 이 가능하며, 이는 고출력을 가지는 녹색광 발생용 LD가 없 는 현실에서 소형화된 광원개발에 도움을 줄 것이다. 그리고 주기변조형 소자를 제작함으로써 파장폭이 넓은 광원 개발이 가능해 fs-pulse laser 이용한 고출력 광원 발생이 가능하다.

특히, 최근 들어, 테라헤르츠파(THz파)의 개발 및 그 응용 에 대해 세계적으로 많은 연구가 진행 중이다. $\mathrm{THz}$ 파는 주파 수 영역대가 약 $0.1 \sim 10 \mathrm{THz}\left(1 \mathrm{THz}=10^{12} \mathrm{~s}^{-1}\right)$ 으로 광원 및 측정방법이 다른 파장대의 빛에 비해 굉장히 부족한 편이 다. 그러나 약 1980 년대부터 전기광학적인 방법 등에 의한 $\mathrm{THz}$ 파의 발생과 측정이 가능하게 됨으로써 연구에 가속을 받 게 되었다. 1984년 광전도안테나를 이용한 발생을 시작으로, 전기광학적 방법뿐 아니라 비선형 광학, 플라즈마, 전자 가속 기 등 다양한 방법에 의해 발생연구가 이루어지고 있다. 이중 에서도, 1992년에 광정류작용(Optical rectification)을 이용 한 발생을 통해, $\mathrm{THz}$ 파 발생이 순수 광학적으로 이루어졌다. 그에 따라, 소형(table-top) 규모의 $\mathrm{THz}$ 파 발생에 대한 연구 가 지금까지 지속적으로 이어져 왔다.

하지만, 테이블 탑 규모에서 비선형 물질을 이용하여 발생 된 $\mathrm{THz}$ 파의 변환 효율은 약 $10^{-10}$ 수준으로 굉장히 낮다. 이 에 따라 효율이 높은 발생방법에 대한 연구가 이루어졌고, 그
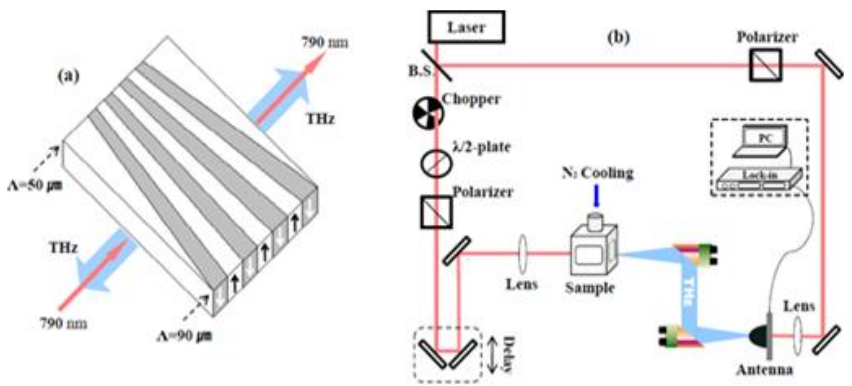

Fig. 2. (a) Fanned-out MgO:PPSLT and (b) THz generation and detection setup.

중에서도, 준위상정합(Quasi-phase-matching) 구조의 물질 을 이용한 $\mathrm{THz}$ 파 발생이 한국을 비롯한 일본, 싱가포르 등에 서 활발히 이루어지고 있다. 이런 준위상정합 구조에서 발생 된 $\mathrm{THz}$ 파는 좁은 파장대를 가지는 특성이 있으며, 발생은 약 $10^{-5}$ 의 변환 효율로 매우 높게 나타난다. ${ }^{[3]}$ 이에 따라, 다양한 형태를 지닌 준위상정합 구조에서 발생된 $\mathrm{THz}$ 파의 특성연구 가 중점적으로 이루어지며, 그 응용에 대한 중요성도 강조되 고 있다.

특히, 고분해능 분광학 및 이미징, $\mathrm{THz}$ 파 센서개발 등에 필수적인 광원으로서 준위상정합구조 기반의 좁은 선폭의 $\mathrm{THz}$ 파 개발이 활발히 이루어지고 있다. 일본의 이화학연구소 (RIKEN)에서는, 우편물 속의 불법 마약유통에 대한 검역으로 좁은 파장대의 $\mathrm{THz}$ 파를 이용한 비침습 이미징의 결과를 보고 하였다. ${ }^{[4]}$ 이는 일반적인 발생형태인 넓은 파장대의 $\mathrm{THz}$ 파로 는 검출이 불가능한 형태로, 좁은 선폭의 $\mathrm{THz}$ 파 광원의 필수 적인 예이다. 또한, 좁은 선폭을 가진 $\mathrm{THz}$ 파는 분자구조 내 의 공명흡수대에서 인접 모드를 제외한 단일 모드만을 여기 시킬 수 있으며, ${ }^{[5]}$ 자유 공간 이미징 및 통신 시스템에서 수 증기에 의한 흡수를 피할 수 있는 장점이 있다. ${ }^{[6]}$

다양한 물질기반의 $\mathrm{THz}$ 응용연구를 위한 주파수 및 선폭 가변한 $\mathrm{THz}$ 파에 대한 요구가 계속됨에 따라 단일 준위상정합 구조를 이용한 주파수 가변한 $\mathrm{THz}$ 파 발생연구가 진행되고 있 다. 준위상정합 기반의 $\mathrm{THz}$ 파 발생에서는 물질의 주기와 온 도에 의해 발생한 $\mathrm{THz}$ 파의 주파수가 결정된다. 이를 이용하 여 부채꼴 모양(fanned-out)으로 준위상정합 주기가 펼쳐진

\section{REFERENCES}

[2] H. Ishizuki and T. Taira, Opt. Express 20, 20002 (2012).

[3] G. H. Kitaeva, Laser Phys. Lett. 5, 559 (2008).

[4] K. Kawase, Y. Ogawa, Y. Watanabe and H. Inoue, Opts. Express 11, 20 (2003)

[5] T. Dekorsy, V. A. Yakovlev, W. Seidel, M. Helm and F. Keilmann, Phys. Rev. Lett. 90, 055508 (2003).

[6] J. Federici and L. Moeller, J. Appl. Phys. 107, 111101 (2010). 


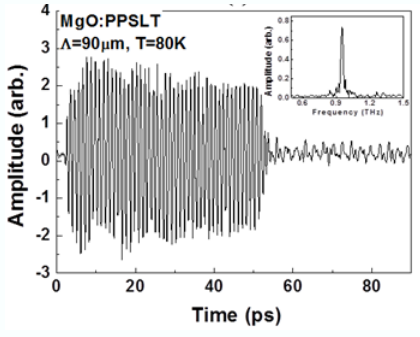

(a)

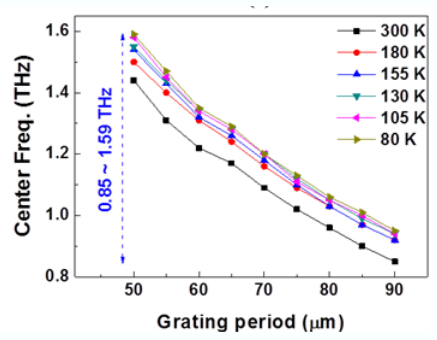

(b)
Fig. 3. (a) Measured $\mathrm{THz}$ waveform and spectrum (inset) and (b) Grating period and temperature dependent $\mathrm{THz}$ frequency output.

구조를 이룬 $\mathrm{MgO}$-doped periodically poled stoichiometic LT(MgO:PPSLT) 크리스탈을 디자인하여 주파수 가변한 THz 파 광원개발이 가능한데, Fig. 2에서와 같이 $800 \mathrm{~nm}$ 파장대 의 펨토초 레이저 광을 주기가 $50 \sim 90 \mu \mathrm{m}$ 사이에서 선형적 으로 변하는 PPSLT를 이용하여 Fig. 3에서와 같이 Muiti-cycle의 $\mathrm{THz}$ 파가 발생되고 약 $25 \mathrm{GHz}$ 의 매우 좁은 선폭을 가 짐을 알 수 있다. 또한, 주기 및 온도를 변화시킴에 따라 $0.85 \sim 1.59 \mathrm{THz}$ 주파수대에서 가변한 $\mathrm{THz}$ 파 발생이 가능하 다.

이와 같은 주파수 가변한 좁은 선폭의 $\mathrm{THz}$ 파는, 탄소 나노 튜브로 만들어진 양자점(Quantum-dot)에서의 전자의 터널링 현상에 있어서 외부 $\mathrm{THz}$ 파의 주파수에 따른 새로운 에너지대 에서의 터널링 현상에 필수 광원으로서 이용될 것이다. ${ }^{[7]}$ 또 한, 다양한 $\mathrm{THz}$ 파 응용분야에서 그 쓰임이 증가되므로, 고출 력의 주파수 및 선폭 가변한 $\mathrm{THz}$ 파에 대한 수요는 지속적으 로 증가할 것이다.

\section{궤도각운동량을 가지는 빛과 이를 이용한 이미징 연구}

요하네스 케플러는 혜성의 꼬리는 항상 태양의 반대방향으 로 향한다고 제안했다. 이는 태양빛이 운동량을 전달하기 때 문이다. 1905년에 존 포인팅은 전자기파는 복사압과 운동량 을 갖는 것을 이론적으로 제시하였다. 그후 아인슈타인은 빛 의 운동량은 $\hbar k$ ( $\hbar$ 는 플랑크 상수 $h$ 를 $2 \pi$ 로 나눈 양이며 $k$ 는 빛의 파수)과 에너지는 $\hbar \omega(\omega$ 는 빛의 진동수)로 양자화되 어 있음을 보였다. 현재 빛의 운동량은 원자 분자의 쿨링이나 트랩에 이용된다. 1909 년에 포인팅은 빛의 원평광은 빛의 각 운동량을 나타냄을 알았다. 그 후 1992년에 L. Allen은 빛의 파면의 공간상 특정분포에 의해 각운동량을 가질 수 있음을 알았으며 빛의 진행에 대하여 방위각 방향으로 위상분포 $e^{i l \phi}$ 를 가지면 각운동량 $l \hbar$ 를 가짐을 예측하였다. ${ }^{[8]}$ 이러한 각운 동량을 갖는 빔의 중심부분에서 위상이 0 에서 $l \times 2 \pi$ 로 간섭 이 이루어져 빛의 강도가 0 이 된다. 그러므로 빛의 진행방향
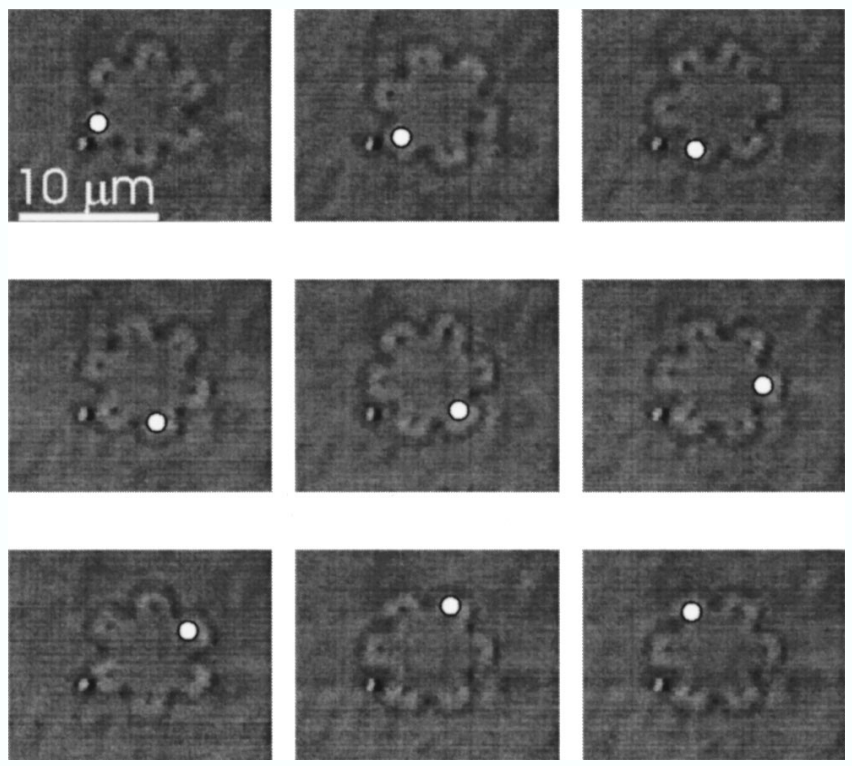

Fig. 4. Rotation of $\mathrm{SiO}_{2}$ structure driven by vortex beam, continuous frames of $0.2 \mathrm{sec}$ interval. ${ }^{[9]}$

에 수직으로 빛의 강도 분포를 보면 도넛 모양임을 알 수 있 다. 빔의 중심부분에서의 위상 정의되지 않는 특성 때문에 위 상 특이(singular) 빛 또는 소용돌이(vortex) 빛이라 불린다. 소용돌이 빛은 발산정도가 작으며 파면에 수직인 운동량 흐 름은 빛의 진행방향에 대하여 나선형으로 형성된다. 각운동량 도 물질로 전달이 가능하다. 이러한 성질을 이용하여 미세가 공이나 Fig. 4 와 같이 원자 분자 트랩에 이용된다. ${ }^{[9]}$

이러한 각운동량을 갖는 소용돌이 빛을 만들기 위해서는 방위각 방향으로 위상이 $l \phi$ 으로 변화하도록 꼬아야 한다. 이는 마치 편평한 링귀니(linguine) 파스타를 꼬인 로티니 (rotini) 파스타로 만드는 과정과 비슷하다.(Fig. 5)

소용돌이 빛을 만들기 위한 방위각 위상 구조는 여러 방법 으로 만들어졌다. 나선형 위상판을 이용하여 방위각으로의 위 상지연을 이용하거나 ${ }^{[10]}$ 허미트-가우시안 모드에서 라게르-가 우시언 모드로 바꾸는 모드변환기를 이용하기도 하며 ${ }^{11]}$ 홀로

\section{REFERENCES}

[7] Y. Kawano, T. Fuse, S. Toyokawa, T. Uchida and K. Ishibashi, J. Appl. Phys. 103, 034307 (2008).

[8] L. Allen et al., Phys. Rev. A 45, 2185 (1992).

[9] M. E. J. Friese, H. Rubinsztein-Dunlop, J. Gold, P. Hagberg and D. Hanstorp, Appl. Phys. Lett. 78, 547 (2001).

[10] M. W. Beijersbergen, R. P. C. Coerwinkel, M. Kristensen and J. P. Woerdman, Opt. Commun. 112, 321 (1994).

[11] M. W. Beijersbergen, L. Allen, H. E. L. O. van der Veen and J. P. Woerdman, Opt. Commun. 96, 123 (1993).

[12] V. Yu. Bazhenov, M. V. Vasnetsov and M. S. Soskin, JETP Lett.(USA) 52, 429 (1990). 


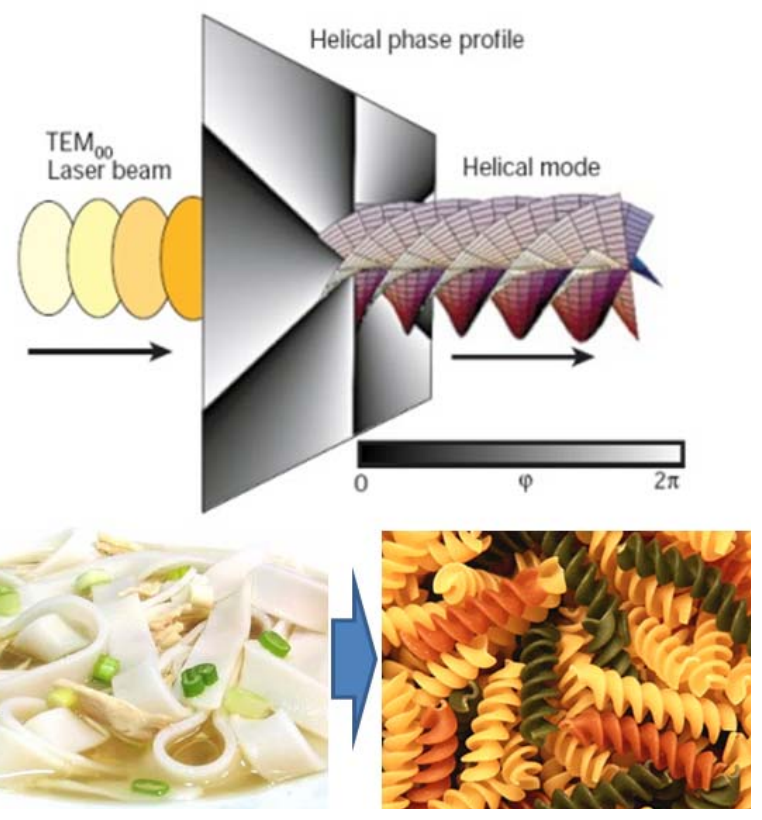

Fig. 5. Transformation from linearly polarized beam to vortex beam.

그램을 이용하는 방법이 있다. ${ }^{[12]}$ 이 방법은 소용돌이 빛과 평면파의 간섭무늬로 홀로그램 패턴을 만들게 되는데, 평면파 를 패턴에 입사시키면 홀로그램의 원리에 의해 소용돌이 빛 이 만들어져 나오게 된다. 요즘은 컴퓨터로 조작이 가능한 공 간광변조기(SLM)를 이용하여 패턴을 만들어 사용한다.

이렇게 소용돌이 빛의 성질을 컴퓨터로 쉽게 조작이 가능 하게 되어 마이크로 머신 회전, 원자 및 분자 트랩, 각운동량 양자얽힘을 이용한 양자정보 ${ }^{[13]}$ 등 다양한 분야에 응용할 수 있다. 여기에서는 소용돌이 빛의 빛 재단(tailoring) 방법과 이를 이용한 나선형 위상대조 현미경 기술에 대하여 소개하 겠다. 빛 재단은 기존에 다른 각운동량을 갖는 두 개의 라게 르-가우시안 또는 베셀광을 합성하여 광바퀴살(optical wheel) 을 만들 수 있다. 액시콘(axicon) 패턴을 이용하면 가우시안 광을 베셀 광으로 변환시킬 수 있는데, 공간광변조기를 이용 하여 그림과 같이 이중액시콘을 이용하면 하나의 가우시안 광을 이용하여 서로 다른 두 베셀 광을 동시에 만들 수 있 다. ${ }^{[14]}$ Fig. 6 의 윗부분의 좌측과 우측은 각각 각운동량 10 과 -10 의 이중액시콘 패턴과 각운동량 3 과 11 의 이중액시콘 패 턴이며 아랫부분은 두 베셀 광의 합성에 의해 생성된 광 바 퀴살의 모습이다.

이러한 소용돌이 빛을 이미징 분야에 응용할 수도 있다. 현 미경의 개발로 미세한 생체세포의 관측이 가능하게 되었지만 이러한 생체세포나 시료들이 투명할 경우 그 영상이 흐릿하 여 관측이 어려운 점이 있다. 그러나 비록 생체세포가 투명하 다고 해도 핵과 염색체 등은 주변과 그 조성차이로 인하여 굴절율이 다르므로 각각의 경계면에서는 위상차이가 발생하
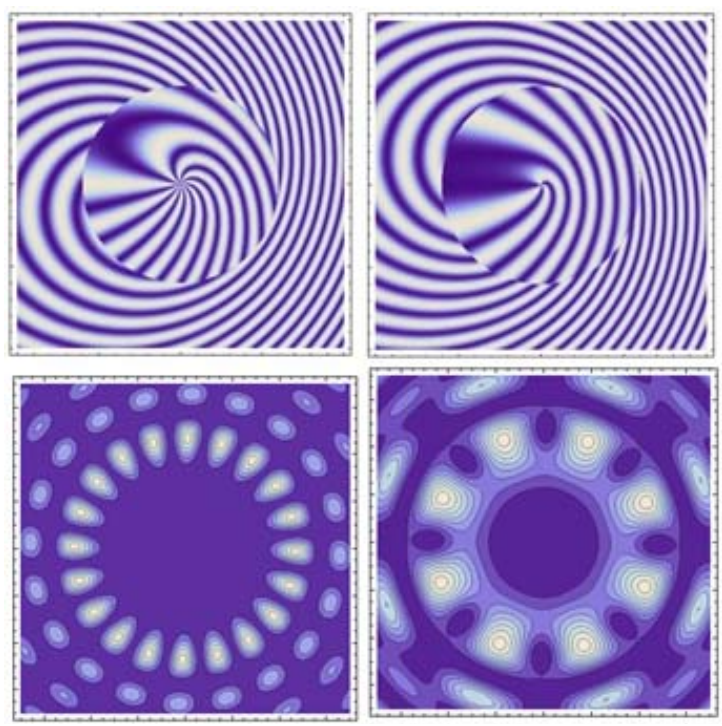

Fig. 6. (up) Double axicon profile, (down) Composition of two Bessel beams.
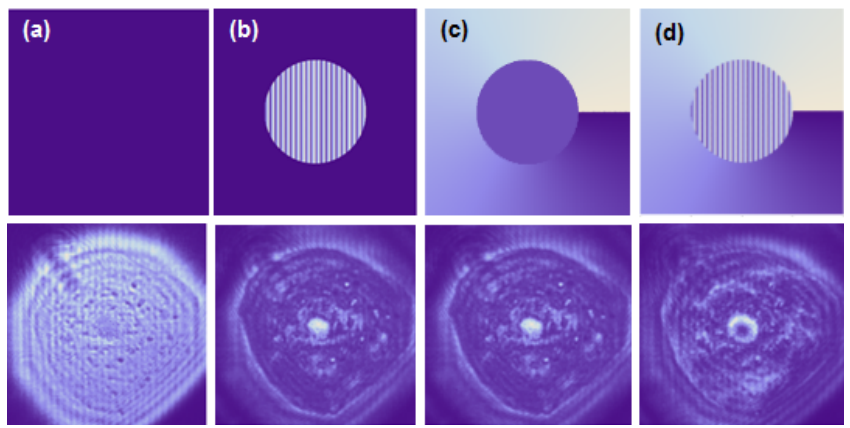

Fig. 7. Observed images of cheek cell (a) without any spatial pattern (b) with only blazed grating center (c) with phase shifted central region with spiral outer (d) with blazed grating center with spiral plate.

게 된다. 이러한 위상차이를 관측함으로써 흐릿한 영상을 개 선하고자 위상대조 현미경개발로 연구가 진행되었다. 소용돌 이 빛은 빛 자체에 공간적인 위상변화가 있어서 일정한 위상 과 빛 세기를 가진 영역에서는 상쇄간섭이 일어나서 물체의 경계면에서만 밝은 빛을 띠게 된다. ${ }^{[15]}$ 높은 대조비를 형성하 기 위해 4-f 광학 시스템에서 푸리에 변환 평면에서 위상 필

\section{REFERENCES}

[13] S. Groblacher, Th. Jennewein, A. Vaziri, G. Weihs and A. Zeilinger, New J. Phys. 8, 75 (2006).

[14] S. I. Hwang, D. H. Song and D.-K. Ko. Japan. J. of Appl. Phys. 50, 042701 (2011).

[15] S. Bernet, A. Jesacher, S. Furhapter, C. Maurer and R. Ritch-Marte, Opt. Express 14, 3792 (2006).

[16] S. I. Hwang, J.-K. Lee, D. H. Song, D. S. Choi and D.-K. Ko, J. Korean Phys. Soc. 58, 387 (2011). 
터링을 사용하며 요즘 일반적으로 위상 필터링으로 $\mathrm{SLM}$ 이 사용되며 Fig. 7 과 같이 다양한 패턴에 따라 세포 내의 구성 성분의 경계의 선명도가 달라짐을 알 수 있다. ${ }^{[16]}$

\section{CARS 분광 이미징 시스템 연구}

눈에 보이지 않는 미시 세계를 관찰하기 위한 인간의 호기 심은 현미경이라는 위대한 발명품을 탄생하게 하였으며, 목적 에 따라 다양한 종류의 현미경들이 개발되고 있다. 그중 가장 많이 사용되는 광학 현미경(Optical microscope)은 일반적으 로 광을 이용하여 크기가 $\mathrm{mm}$ 이하의 샘플을 직접 볼 수 있 는 장비를 말한다. 대표적인 광학 현미경인 위상차 현미경, 미분 간섭 현미경, 형광 현미경, 편광 현미경 등은 넓은 영역 을 실시간으로 볼 수 있지만 공간 분해능이 낮은 단점을 가 지고 있다. 하지만 1960년에 레이저가 개발됨으로써 레이저 를 이용한 현미경 덕분에 위와 같은 단점을 극복할 수 있었 다.

오늘날 생명과학 및 의광학 분야에서 세포나 조직을 관찰 하기 위하여 가장 많이 사용되고 있는 것이 바로 '공초점 레 이저 스캐닝 현미경'(confocal laser scanning microscopy, CLSM)이다. 공초점(confocal)이란 광원이 되는 레이저에서 시료의 초점과 맞지 않는 빛은 제거하고 초점과 일치하는 빛 만 사용한다는 뜻으로, CLSM은 초점이 정확하게 맞는 빛만 을 조리개로 분리한 뒤 포토다이오드와 같은 검출기로 받아 디지털 신호로 바꿔 컴퓨터로 관찰하는 방법이다. CLSM은 레이저가 시료의 내부까지 깊이 침투할 수 있기 때문에 윗부 분부터 아랫부분까지 단층 이미지를 촬영하면 3차원 입체 영 상으로 관찰할 수도 있다. 이런 장점 때문에 CLSM은 생물학 연구의 필수 장비로 자리를 잡았다. 그러나 관찰을 위해서는 세포에 형광물질을 투여해야만 하는데, 시간이 지나면 형광 체의 발광이 사라져 지속적인 관찰이 힘들게 되는 광표백 (photobleaching) 현상이 발생하고, 형광체의 독성으로 인하 여 심지어 샘플이 죽게 되는 치명적인 단점을 가지고 있어 살아있는 세포를 연구하기엔 한계가 있다.

이러한 문제점을 극복하기 위해 개발되고 있는 방법이 바 로 비선형 현상을 이용하는 라만 현미경이다. 모든 물질은 고 유한 진동수를 갖고 있기 때문에 빛을 비추면 빛과 물질과의 사이에 에너지 교환이 일어난다. 이 과정에서 원자·분자의 진 동 상태, 회전 상태가 변한다. 따라서 단일 파장의 레이저를 비추면 처음보다 약간 길거나 짧은 파장의 스펙트럼선이 나 온다. 이를 분석해 영상으로 만든 것이 바로 '라만분광현미경' 이다. 대표적인 라만분광현미경 중에 하나가 바로 간섭성 반 스톡스 라만 산란(Coherent anti-stokes Raman Scattering,
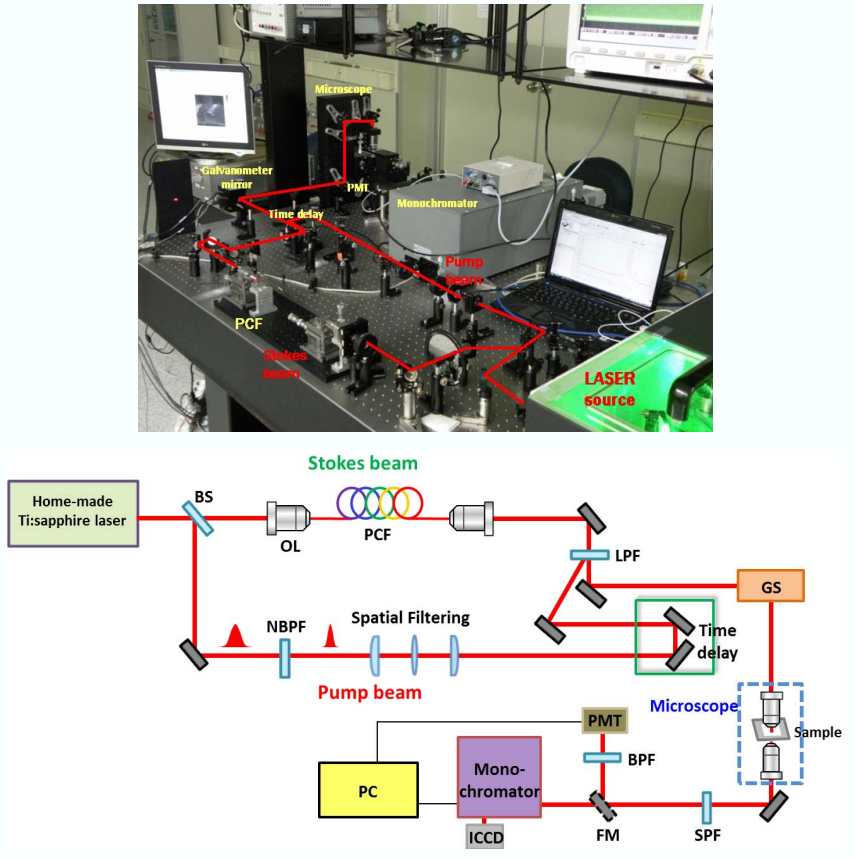

Fig. 8. Photograph(top) and schematic(bottom) of our CARS microspectroscopy imaging system.

CARS) 신호를 이용한 'CARS 분광 현미경'이다. 방출되는 다 양한 파장의 빛 가운데 특정한 빛을 선택하는 CLSM과 달리, $\mathrm{CARS}$ 는 원하는 세포부위 분자의 진동을 강하게 유도하는 파 장의 빛을 광원으로 쓴다. 기본적으로 CARS는 최소 두 개의 서로 다른 파장을 가지는 펌프와 스톡스 광원이 필요하다. 그 리고 펌프와 스톡스 광원이 시간적·공간적으로 정확하게 일 치하게 되면 새로운 파장의 anti-Stokes 신호가 발생하게 되 는데, 이 신호를 이용하여 분광분석이나 이미징을 할 수 있 다. 이 방식을 쓰면 방출되는 신호의 세기를 획기적으로 증대 시킬 수 있기 때문에 세포에 형광물질을 투여하지 않고도 해 상도가 높은 이미지를 얻을 수 있는 큰 장점을 갖는다. 따라 서 살아있는 세포의 실시간 이미징이 가능하다.

CARS 현미경은 CARS 분광학 연구가 시초가 되었는데, 1965년 Maker와 Terhune 등에 의해 처음 연구되었고, ${ }^{[17]}$ 현재 가장 잘 알려진 비선형 기술 중의 하나가 되었으며, 신 호 감도가 자발 라만에 비해 $10^{5}-10^{7}$ 배 이상 크기 때문에 자동차 엔진이나 비행기 제트엔진의 화학적 성분 분석이나 온도 측정, 고체 물질의 성분 분석 등을 하는데 사용되었다. 1982년 Duncan과 그의 동료들이 최초로 CARS 분광학을

\section{REFERENCES}

[17] P. D. Maker and R. W. Terhune, Phys. Rev. 137, A801 (1965).

[18] M. D. Ducan, J. Reintjes and T. J. Manuccia, Opt. Lett. 7, 350 (1982) 


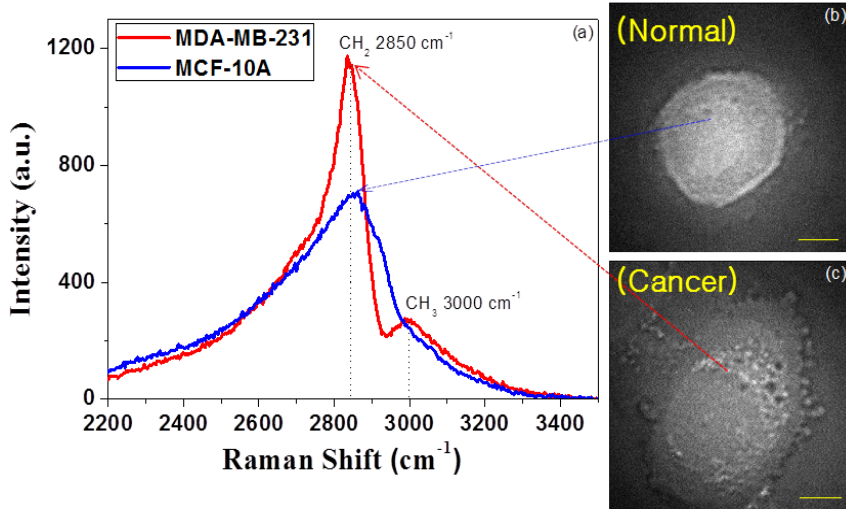

Fig. 9. Comparison between breast normal(MCF-10A) and cancer (MDA-MB-231) cell samples using a CARS spectrum and image. CARS spectra of (a) normal cell (blue line), cancer cell (red line), and non-resonant signal generated by the glass bottom of the confocal dish (black dot line). CARS images $\left(60 \times 60 \mu \mathrm{m}^{2}, 300 \times\right.$ 300 pixels) of (b) non-tumorigenic cell and (c) breast carcinoma cell in $\mathrm{C}-\mathrm{H}$ stretching vibration region. The acquisition time is within 10 s. The scale bar in the images is $10 \mu \mathrm{m} .{ }^{[22]}$

현미경에 적용하는 실험을 성공적으로 수행하였다. ${ }^{[18]}$ 그 후 1999년 Zumbusch 등이 근적외선 레이저 광을 사용하여 강 하게 집속된 동일선 방식의 실험에서 신호 대 잡음비가 상당 히 증폭한 전방방향으로 CARS 신호를 검출하였고, ${ }^{[19]} 2000$ 년대 후반부터 CARS 현미경이 본격적으로 연구되기 시작하 면서, 근래에 CARS 현미경 연구가 활발히 진행 중에 있다.

기본적으로 CARS 현미경은 두 파장의 레이저광이 필요한 데 두 대의 동기화된 피코초 레이저를 사용함으로써 분광 분 해능을 개선시킬 뿐만 아니라 신호 대 잡음비를 증가시킬 수 있다. 레이저 기술 발전의 가속화는 CARS 현미경 연구에 많 은 영향을 주었다. 레이저 스캐닝 방식을 사용하여 살아있는 바이오 샘플에 적용하여 현재는 살아있는 세포를 실시간으로 관측할 수 있게 되었다. ${ }^{[20]}$ 최근에는 각국에서 CARS 현미경 연구를 본격화하기 시작하였으며 현재 CARS 현미경을 의료 용 장비에 사용하기 위한 'CARS 내시경' 연구도 활발히 진행 되고 있다. ${ }^{[1]}$

한편 한 대의 펨토초 레이저만을 사용한 CARS 연구도 진 행되고 있는데 이 경우 Fig. 8와 같이 펌프 광원을 두 개로 나누고 그 중 하나의 광원은 $\mathrm{PCF}$ (photonic crystal fiber)를 이용하여 광대역 광원을 만들게 된다. 발생한 광대역 광원을 스톡스 광원으로 사용하고, 펌프와 스톡스 광원을 정확하게 일치시켜 샘플에 집속시키면 CARS 신호가 발생하게 된다. 넓은 파장의 스톡스 광원을 사용하면 동시에 많은 CARS 신 호를 관측할 수 있게 되는데 이를 multiplex CARS라고 한 다. 이를 통하여 한 번에 $500-4000 \mathrm{~cm}^{-1}$ 에 해당하는 넓은
영역을 빠른 시간에 높은 해상도와 민감도를 제공하며 측정 할 수 있다. 이러한 multiplex CARS 시스템은 의료분야에 이용하여 Fig. 9의 결과와 같이 유방암과 정상세포를 CARS 분광 및 CARS 이미징을 통해 구분이 가능하여 유방암을 조 기에 진단하는 강력한 시스템으로 사용이 가능할 것으로 전 망되고 있다. ${ }^{[2]}$ 또한 간 조직, 뇌세포 조직, 동맥경화 등 다 양한 질병을 연구하는데 CARS 분광 현미경을 응용하고 있 다. 더 나아가 CARS 뿐만 아니라 동일한 라만 현상을 이용 하는 유도 라만 산란(Stimulated Raman scattering), 라만 유도 커효과 산란(Raman-induced Kerr-effect scattering) 등의 기술을 하나의 시스템에 구현하게 되면 각각의 장단점 을 보완할 수 있는 분광 현미경 기술로써 물리, 화학, 의료, 바이오, 산업 영역에서 많은 역할을 할 것으로 기대된다.

\section{맺음말}

본 글에서는 극초단 비선형 광학연구에 대하여 간단히 기 술하였다. 주로 저자가 관심을 가지고 현재 연구하는 분야를 위주로 소개하다보니 본 내용에서 소개되지 않은 연구 분야 가 아주 많이 있다. 극초단 초고출력 레이저 개발 및 응용연 구와 초고해상도 광학현미경 연구 등은 이미 본 잡지 2012 년도 4월호 및 5 월호에 자세히 소개된 바가 있어서 여기서는 생략하였다. 많은 사람들이 이미 20세기가 전자의 시대였다 면 21세기는 광자의 시대가 될 것으로 예측하였으며, 이미 그 연구 대상이 나노사이즈와 펨토초 영역 나아가 아토초 영 역으로 확대되고 있으므로 원자나 분자 세계의 초고속 동력 학이나 나노 물질 및 생체 물질의 순간적인 변화를 관측하기 위해서는 극초단 비선형 광학연구가 필수적이라고 하겠다. 이 러한 연구들은 점차 자연과학의 근본 원리를 탐구하고 아직 해결하지 못한 인류가 직면한 에너지, 환경, 질병문제들을 해 결하는 방안을 모색하는 방향으로 진행되고 있으므로 극초단 비선형 광학 연구는 앞으로 순수과학뿐만 아니라 우리의 일 상생활을 윤택하고 건강하게 하는데 기여할 것이다.

\section{REFERENCES}

[19] A. Zumbusch, G. R. Holtom and X. S. Xie, Phys. Rev. Lett. 82, 4142 (1999).

[20] C. L. Evans, E. O. Potma, M. Puoris'haag, D. Côté, C. P. Lin and X. S. Xie, Proc. Natl. Aca. Sci. 102, 16807 (2005).

[21] F. Légaré, C. L. Evans, F. Ganikhanov and X. S. Xie, Opt. Express 14, 4427 (2006).

[22] J. H. Lee, E. H. Cho, S.-M. Shin, M.-k. Oh and D.-K. Ko, Appl. Phys. Express 5, 08240 (2012). 